\title{
Peningkatan Ekonomi Rumah Tangga Melalui Budidaya Sayuran Organik Berbasis Kemitraan Dan Berwawasan Lingkungan di Kelurahan Jebres Surakarta
}

\author{
Djoko Purwanto |Catur Sugiarto| Pram Suryanadi | Tastaftiyan Risfandy | Sunarjanto | Muhammad Yusuf Indra Purnama \\ Fakultas Ekonomi dan Bisnis, Universitas Sebelas Maret Surakarta
}

\begin{abstract}
Abstrak
Peningkatan Ekonomi Rumah Tangga Melalui Budidaya Sayuran Organik Berbasis Kemitraan dan Berwawasan Lingkungan di Kelurahan Jebres Surakarta dimaksudkan untuk memberikan salah satu alternatif bagi pemenuhan kebutuhan sayuran organik yang sehat bagi keluarga di wilayah Kelurahan Jebres Surakarta. Kegiatan tersebut dimaksudkan selain pemenuhan terhadap kebutuhan sayuran yang sehat, tetapi secara ekonomis juga memberikan manfaat terhadap penghematan pengeluaran belanja sehari-hari khususnya sayuran. Di sisi yang lain, budidaya tanaman sayuran organik yang sehat, segar dan hijau memberikan dampak positif terhadap lingkungan sekitarnya yang semakin asri dan sehat. Kegiatan Pengabdian Kepada Masyarakat ini melibatkan ibu-ibu PKK di wilayah Kelurahan Jebres termasuk ibu-ibu PKK RW 10 Jebres Surakarta sebagai salah satu mitra dalam berbudidaya sayuran organik. Ibu-ibu PKK RW 10 Jebres Surakarta nantinya akan memperoleh ilmu praktis tentang budidaya sayuran organik yang dapat diaplikasikan dikemudian hari. Disamping itu peserta akan memperoleh bekal bertanam yang berupa media tanam dan benih sayur, misalnya: sawi, kangkung atau selada.
\end{abstract}

Kata Kunci: Budidaya Sayuran Organik, Kemitraan, Berwawasan Lingkungan

\section{Pendahuluan}

Kelurahan Jebres merupakan salah satu kelurahan di wilayah Kecamatan Jebres, kota Surakarta yang memiliki wilayah yang cukup besar dan juga jumlah penduduknya yang juga besar. wilayah Kecamatan Jebres mencakup 12 wilayah Kelurahan, antara lain: Kelurahan Mojosongo, Jebres, Tegalharjo, Pucangsawit, Kepatihan Kulon, Kepatihan Wetan, Sudiroprajan, Gandekan, Sewu, Jagalan, Jagalan, dan Purwodiningratan. Kelurahan Jebres memiliki 36 RW (Rukun Warga) dan 128 RT (Rukun Tetangga). Setiap RW terdiri atas beberapa RT antara 3 RT hingga 6 RT. Total luas wilayah Kelurahan Jebres adalah 317 Ha. Kelurahan Jebres berbatasan dengan wilayah lain, dimana sebelah utara berbatasan dengan Kelurahan Mojosongo, sebelah selatan dengan Kelurahan Purwodiningratan, sebelah timur dengan Kabupaten Karanganyar, dan sebelah barat dengan Kelurahan Tegalharjo. Rukun Warga (RW) 10 merupakan salah satu bagian wilayah yang ada di Kelurahan Jebres, Kecamatan Jebres Kota Surakarta. Sebagaimana diketahui bahwa di Kelurahan Jebres terdiri atas 36 RW dimana setiap RW terdiri atas beberapa RT yang antara satu dengan yang lainnya berbeda.

Sementara untuk inisiatif kegiatan ekonomi masyarakat yang terkait dengan alternatif budidaya tanaman sayur secara organik belum banyak dilakukan oleh masyarakat. Padahal kalau kegiatan budidaya tanaman sayur secara organik tersebut dikembangkan di masyarakat, khususnya di wilayah Kentingan RW 10, maka secara ekonomi masyarakat akan memperoleh hasil panenan sayur tersebut yang pada akhirnya mereka akan dapat melakukan penghematan pengeluaran belanja sayuran setiap harinya. Apalagi jenis tanaman sayur yang akan dibudidayakan adalah jenis sayuran organik yang bebas dari unsur kimia dan tanpa pestisida. 
Usaha yang mengutamakan keseimbangan alam dan berwawasan lingkungan serta berbasis kemitraan kepada komunitas sosial di sekitar menjadi kunci kesuksesan keberlanjutan suatu proses bisnis dan langsung memberikan manfaat kepada masyarakat sekitar. Pada konteks ini, Green business menjadi topik hangat yang menarik. Isu kelestarian lingkungan, banyaknya makanan anak-anak yang tidak sehat telah menyadarkan serta mendorong masyarakat akan arti pentingnya hidup sehat, kebutuhan produk dan jasa yang ramah lingkungan. Green Business merupakan aktivitas bisnis menjadi produk (barang dan jasa) dengan mengutamakan keseimbangan dan sinergi antara keuntungan ekonomi, social, dan lingkungan (Mutamimah dan Siyatimah, 2012). Hal ini telah ditegaskan pada beberapa literature pada bidang pemasaran bahwa kesadaran terhadap produk dapat membantu konsumen dan masyarakat dalam mengambil keputusan beralih kepada pilihan hidup yang lebih sehat (Macdonald \& Sharp, 2000).

Berdasarkan fakta dan perlunya usaha yang mengutamakan keseimbangan alam dan berwawasan lingkungan serta berbasis kemitraan kepada komunitas sosial, maka program pengabdian pada masyarakat yang melibatkan ibu-ibu PKK di wilayah Kelurahan Jebres termasuk ibu-ibu PKK RW 10 Jebres Surakarta perlu dilakukan, utamanya dalam bentuk sosialisasi dan pelatihan budidaya sayuran organik yang berbasis kepada kemitraan dan yang mengedepankan wawasan lingkungan. Pelatihan ini diharapkan dapat meningkatkan ekonomi keluarga dan rumah tangga serta dalam lingkup yang lebih luas dapat menumbuhkan potensi ekonomi daerah dan kesejahteraan masyarakat.

\section{Metode Pelaksanaan}

Kegiatan ekonomi masyarakat di perkotaan dengan tingkat kepadatan rumah yang sangat tinggi dan ketersediaan lahan yang semakin terbatas, maka dengan sendirinya sulit bagi mereka untuk melakukan kegiatan budidaya tanaman sayur sebagaimana mestinya. Namun demikian, seiring dengan kemajuan teknologi, informasi dan komunikasi, maka dengan sendirinya masyarakat juga perlu mengikuti perubahan yang terjadi. Dalam perkembangannya di dunia praktis, budidaya tanaman sayur secara organik sangat mungkin dilakukan meskipun di lahan yang sangat terbatas. Oleh karena itu yang menjadi fokus permasalahannya adalah bagaimana melakukan budidaya tanaman sayur secara organik dapat dilakukan di lingkungan pemukiman yang lahannya sangat terbatas tersebut. Solusinya disini adalah dengan sosialisasi pentingnya usaha dengan berwawasan lingkungan (green business) serta adalanya pelatihan secara praktis dalam budidaya sayuran organik dengan berbasis kemitraan dan berwawasan lingkungan.

Pada pelaksanaan pengabdian ini, beberapa tahapan disampaikan:

1. Melakukan koordinasi dengan pengurus PKK RW 10 terkait dengan rencana melakukan sosialisasi tentang budidaya tanaman sayur secara organik kepada warga masyarakat. Pada tahap ini peserta dijelaskan bagaimana pentingnya melalukan usaha tanpa harus merusak lingkungan dan pentingnya kerjasama dan kemitraan dalam menjalankan usaha secara bersamasama yang menjadi ciri khas dari usahan ini yang menjadi fitur penting dan menjadi asset yang sangat berharga.

2. Menentukan keterwakilan dari masing-masing RT untuk mengikuti kegiatan sosialisasi tersebut. Selanjutnya ditentukan jumlah pesertanya secara merata berdasarkan jumlah warganya.

3. Mempersiapkan agar setiap peserta dalam kegiatan sosialisasi tersebut disamping memperoleh ilmu, juga bahan-bahan yang diperlukan dalam kegiatan praktik di rumah mereka masingmasing (misalnya: benih, pupuk, media tanam dan alat bantu lainnya). Pendampingan di lapangan ketika mereka mempraktikkan budidaya tanaman sayur tersebut di rumah mereka masing-masing. 
Jurnal SEMAR Vol. 8 No.1, 2019 hal. 50-54

\section{Hasil dan Pembahasan}

Kegiatan sosialisasi dan pendampingan budidaya sayuran organik dengan berbasis kemitraan dan berwawasan lingkungan ini seiring dengan program pemerintah untuk membantu meningkatkan pendapatan masyarakat, serta membantu masyarakat terutama dalam mendukung keberlanjutan usaha yang sudah mereka rintis yang pada akhirnya dapat menjadi salah satu program pengentasan kemiskinan.

Kegiatan ini diawali dengan penjelasan sekilas tentang bagaimana budidaya sayuran sehat baik itu tanaman secara organik maupun hidroponik dengan lahan yang sangat terbatas. Budidaya tanaman sayuran sehat ini sangat cocok diterapkan di lingkungan perkotaan maupun lingkungan perumahan. Mengapa demikian, hal ini mengingat bahwa pada umumnya di wilayah perkotaan maupun di lingkungan perumahan pada umumnya memiliki lahan terbuka yang sangat terbatas. Oleh karena itu, model ini sangat cocok diterapkan di lingkungan tersebut.

Secara garis besar, dalam berbudidaya sayuran sehat memiliki beberapa tahapan penting yang dimulai dari tahap persemaian, penanaman, pemeliharaan, panen dan paska panen.

Pada tahap persemaian merupakan tahapan paling awal dalam berbudidaya sayuran dimana benih ditaburkan pada tempat persemaian yang sudah disiapkan dan usahakan media tanamnya gembur atau subur agar benih dapat tumbuh dengan cepat dan baik.

Pada tahap selanjutnya adalah tahap penanaman dimana pada tahapan ini bibit yang sudah cukup umur selanjutnya dipindahkan ke tempat pembesaran. Pada tempat ini nantinya bibit tanaman tersebut bisa tumbuh dengan baik.

Pada tahap berikutnya adalah tahap pemeliharaan atau perawatan. Tahapan perawatan ini merupakan tahapan penting dan sangat menentukan nasib tanaman kedepan. Dalam hal ini perlu dilakukan pemantauan secara terus menerus bagaimana perkembangan tanaman sayuran tersebut selanjutnya. Pada tahapan ini perlu dipantau bagaimana pertumbuhan tanamannya, media tanam yang digunakan, kondisi tanamannya dan hama pengganggu tanaman tersebut.

Pada tahap selanjutnya adalah tahap panen. Ketika usia tanaman dianggap cukup untuk dipanen, maka perlu segera dilakukan pemanenan tanaman sayur tersebut dengan cara-cara tertentu. Sebagaimana diketahui bahwa usia panen tanaman sayur antara yang satu dengan yang lain memiliki usia yang berbeda-beda. Misalnya tanaman sayur kangkung dan sawi memiliki masa usia panen yang berbedabeda. Kangkung sudah layak dipanen maksimal dalam usia satu bulan, sedangkan tanaman sayur sawi baru bisa dipanen sekitar dua atau tiga bulan usia tanamnya.

Setelah tahap panen, maka tahap berikutnya adalah tahapan paska panen dimana pada tahapan ini perlu dilakukan perombakan ulang media tanaman yang digunakan tersebut. 
Jurnal SEMAR Vol. 8 No.1, 2019 hal. 50-54

ISSN: 2302-3937 | Copyright @ LPPM Universitas Sebelas Maret Homepage: https://jurnal.uns.ac.id/jurnal-semar
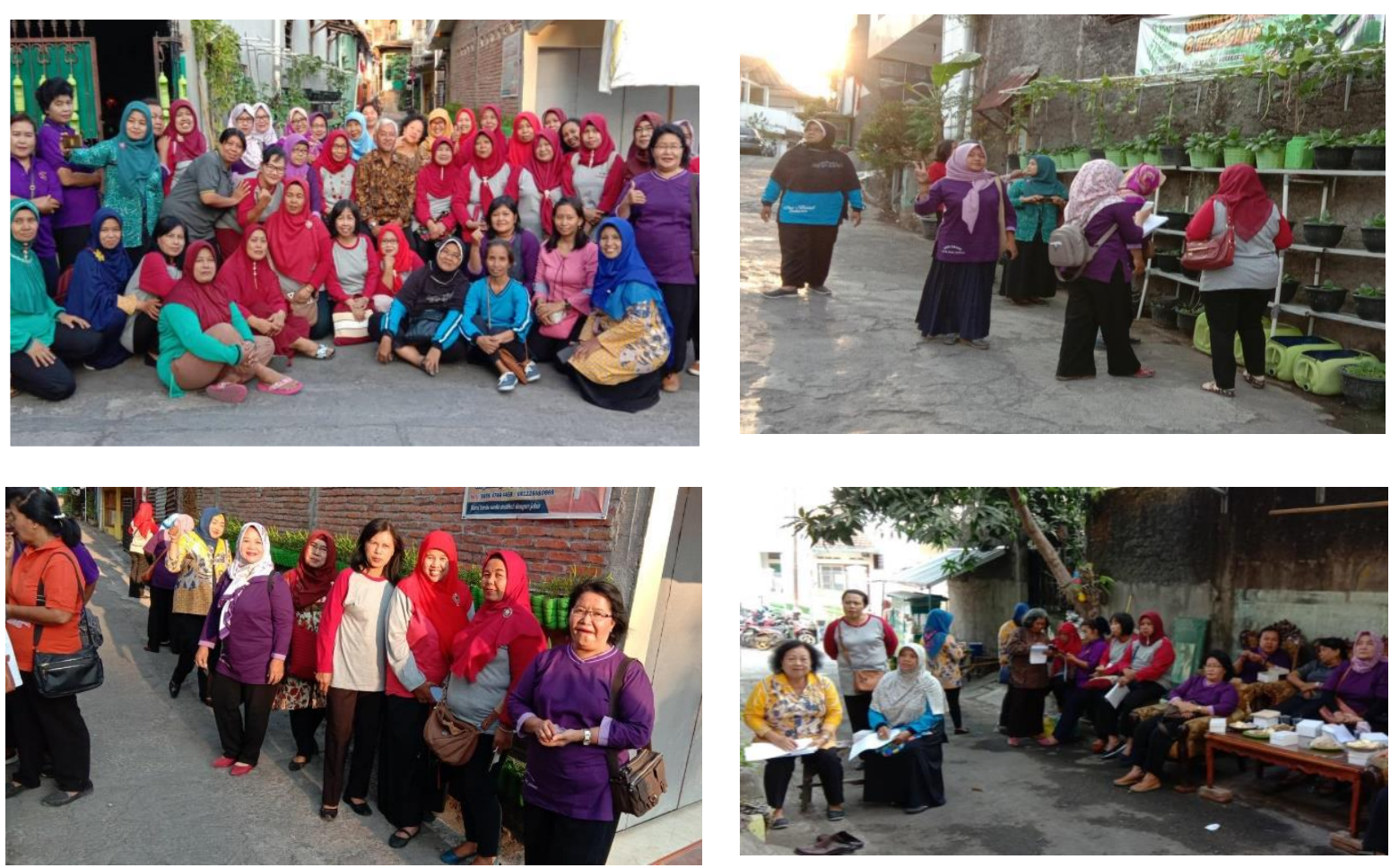

Gambar 1. Sosialisasi dan Pelatihan Budidaya Sayur Organik

Strategi yang coba dikembangkan dalam menumbuhkan usaha yang berwawasan lingkungan (green business) yang berbasiskan kemitraan dirasa cukup efektif dan efisien karena didukung dengan adanya partisipasi aktif masyarakat dalam persepsi mereka tentang pentingnya menjalankan usaha dan memproduksi output dalam hal ini sayuran organik berkembang pesat di kalangan masyarakat Indonesia secara luas.
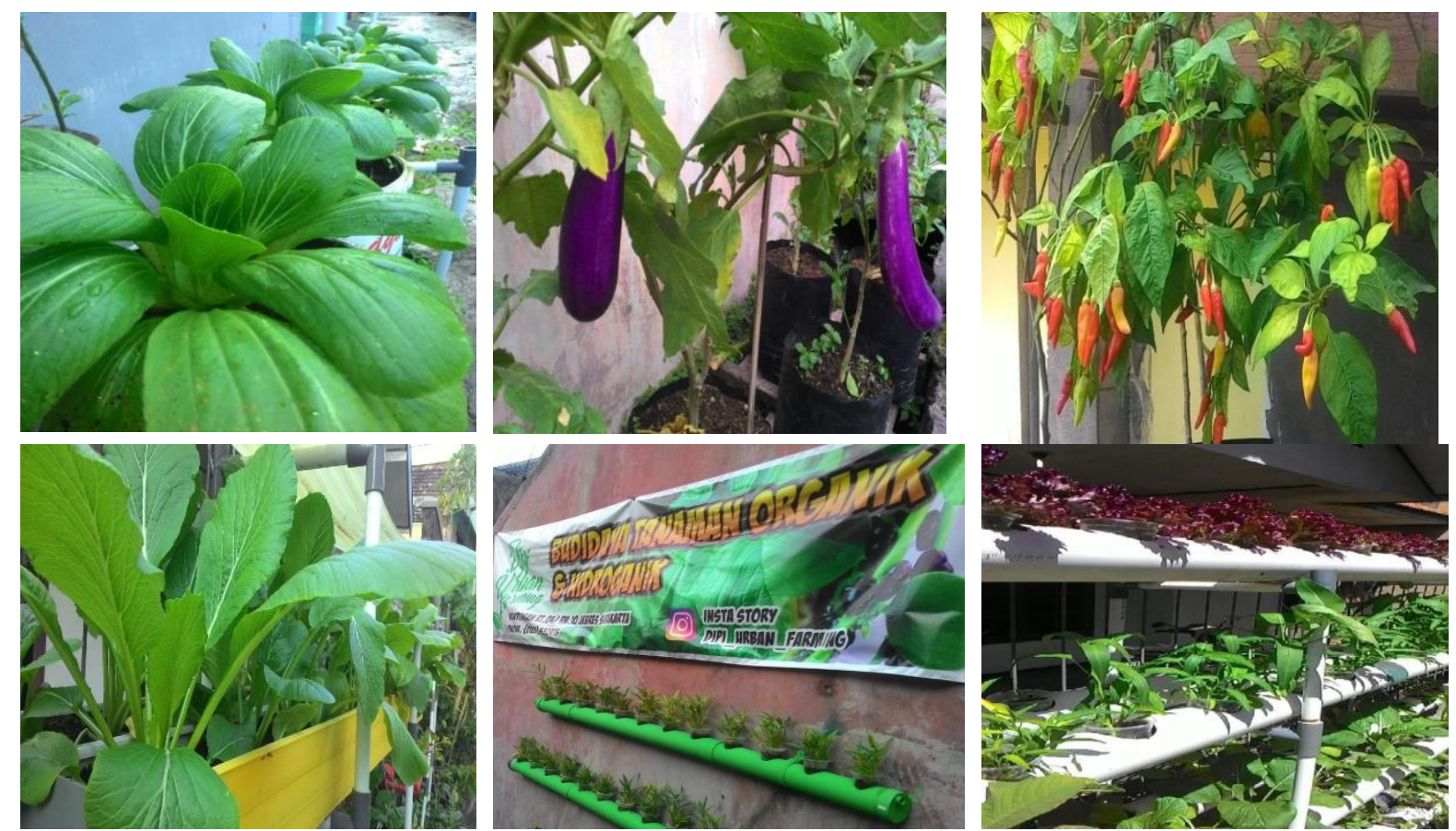

Gambar 2. Produk hasil budidaya sayuran organik 
Hasil produksi budidaya sayuran organik mempunyai karakteristik dan kandungan yang berbeda-beda. Kandungan zat-zat yang ada di dalam sayuran organik bisa memberikan manfaat yang lebih baik untuk kesehatan tubuh. Bahkan dapat mencegah serta mengobati berbagai macam penyakit. Terlebih lagi sayuran yang ditanam secara organik pada umumnya tak mengandung residu bahan kimia di dalamnya.

Pada budidaya organik akan mengurangi bahkan menghilangkan dampak negatif yang ditimbulkan oleh pemakaian bahan kimia. Lebih menitikberatkan penggunaan pupuk organik dan pupuk hayati pada sayuran sehingga mempunyai berbagai keunggulan bila dibandingkan sayuran non organik dengan penggunaan pestisida kimia dan pupuk kimia.

\section{Penutup}

Kegiatan pengabdian masyarakat melalui sosialisasi dan pendampingan Peningkatan Ekonomi Rumah Tangga Melalui Budidaya Sayuran Organik Berbasis Kemitraan dan Berwawasan Lingkungan di Kelurahan Jebres Surakarta ini sangat bermanfaat secara langsung dan sangat mudah diterapkan oleh masyarakat pada umumnya. Saat pelatihanpun warga menyampaikan bahwa pelatihan semacam ini sangat bermanfaat dalam meningkatkan penghasilan ekonomi rumah tangga utamanya dalam aspek kewirausahaan. Pada sesi akhir pelatihan, warga langsung mengaplikasikan konsep budidaya sayur organik dengan langsung mempraktekkan cara budidaya sayur organik mulai dari pembibitan hingga pasca panen. Melalui pelatihan dan program pengabdian ini diharapkan mampu mengembangkan potensi masyarakat dalam memanfaatkan sumber daya alami di sekitar lingkungannya yang potensial. Oleh karena model yang digunakan dalam berbudidaya sayuran tersebut sangat sederhana, mudah, praktis dan murah meriah, maka model ini diharapkan sangat mudah di aplikasikan dan mudah menyebar ke daerah-daerah yang lainnya sehingga dampaknya terhadap perekonomian suatu daerah juga akan terasa secara signifikan.

\section{Referensi}

Macdonald, E. K., \& Sharp, B. M. (2000). Brand Awareness Effects on Consumer Decision Making for a Common, Repeat Purchase Product: A Replication. Journal of Business Research, 48, 515.

Mutaminah dan Siyatimah. 2012. Model Pengembangan Green Business untuk Peningkatan Kinerja Keuangan dan Kinerja Pasar, Proceeding Forum Manajemen Indonesia (FMI), Yogyakarta, 2012.

Suryana. 2003. Kewirausahaan, Pedoman Praktis: Kiat dan Proses Menuju Sukses, Salemba Empat Tulus Tambunan.2002. Usaha Kecil dan Menengah di Indonesia, Beberapa Isu Penting, Salemba Empat 